\title{
A „HIDEGHÁBORÚ” ÉS ANNAK PSZICHOLÓGIAI TEREPE
}

Szerző:

Kemény László (PhD, CSc)

nyugalmazott egyetemi tanár

Szerző e-mail címe:

kemeny.m.laszlo@gmail.com

\section{Lektorok:}

Koncz István (PhD, CSc)

Professzorok az Európai

Magyarországért Egyesület)

Mező Ferenc (PhD)

Eszterházy Károly Egyetem

...és további két anonim lektor

\section{Absztrakt}

E tanulmány rövid áttekintést nyújt a hidegháború időszakáról (1946-1989). A második világháború utáni években a két nagyhatalom (az Amerikai Egyesült Államok és a Szovjetunió) a politika, a gazdaság és a tudomány területén versenyeztek egymással az emberek lelkének megnyerése érdekében. Jellemző fegyverük volt a propaganda és a pszichológiai hadviselés.

Kulcsszavak: hidegháború, propaganda

Diszciplinák: politológia, történelem, pszichológia

\section{Abstract}

THE 'COLD WAR' AND ITS PSYCHOLOGICAL TERRAIN

This study provides a short overview of the interval of the Cold War (1946-1989). These years after World War II, the two superpowers (the United States of America and the Soviet Union) were competing with each other in the area of politics, economy, and sciences to win the people's souls. Their characteristic weapons were the propaganda and psychological warfare.

Keywords: Cold War, propaganda

Disciplines: politology, history, psychology

Kemény László (2019): A „hidegháború” és annak pszichológiai terepe. Lélektan és hadviselés - interdiszciplináris folyóirat, I. évf. 2019/1. szám. 27-42.

doi: $10.35404 /$ LH.2019.1.27 
A „kapitalista” és a „szocialista” világrendszerek kibékíthetetlen harca határozta meg a XX. század második felének történéseit. A hidegháború történetének részletes taglalása ma már a politikai és a társadalomtudományi irodalom fontos része. Természetesen mindenki a saját vizsgálati szempontjai és érdekpozíciói szerint tárgyalja.

Tény, hogy a II. világháborúban a Szovjetunió a szövetségesek végjátékbeli támogatásával legyőzte a hitleri fasizmust, az USA pedig mindennek gazdasági győztese lett. Kétpólusúvá vált a világ, amelyben a Szovjetunió és az Amerikai Egyesült Államok a befolyási övezeteik szélesítésével, maguk és mások felfegyverzésével vigyázták a két szuperhatalom erőegyensúlyát.

A Szovjetunió azonban, születésétôl fogva „önmagába zártnak" érezte a helyzetét a világban. Ez az érzet az 1918-1922 közötti intervenciótól kezdve, az azt követően a vele szemben alkalmazott gazdasági, politikai szankciók érvényesítésén át, a II. világháború előkészületeinek szovjet-ellenes ideológiai és hadiipari törekvései alapján alakult ki, és a Hitler ellenes szövetség létrejötte, sikere és távlatos fenntarthatósága reményének ellenére felerôsödött, s a körbezártságot megerōsítô hidegháborúval csúcsosodott ki.

\section{A hidegháború}

A hidegháború idôszakában kettôs folyamat zajlott le:

1) A fejlett országok szinte minden felől fôként ideológiai, gazdasági és politikai szempontból - „zár alá vették” a Szovjetuniót.
2) A Szovjetunió pedig (részben védekezésként) „bezárkózott” s majdnem teljes körű „önellátásra” rendezkedett be.

A hidegháború lezárásának ,indítógombját" Ronald Reagannek, az USA elnökének a londoni parlamentben 1982. június 8-án elmondott beszéde ,nyomta le”. Ennek a szövegnek a meghatározó kitétele volt, hogy a Szovjetunió a „gonosz birodalma” és ezért „a történelem hamudombján hagyjuk a marxizmust-leninizmust" (Reagan, 1982). A politikai cselekvés nyelvére lefordítva, ez azt jelentette, hogy a Nyugat a hidegháborút győztesen akarta befejezni, és ennek a feltétele és egyben célja is a marxizmus-leninizmus ideológiájának kiiktatása a történelemből.

A Szovjetunió a vasfüggöny kialakulásával „külső-belső” izolációban rekedt. Egyrészt kirekesztették, mint nem egyenrangú felet, sőt ellenséget; másrészt - reflektálva a „kirekesztésre" - be is zárkózott, és a jaltai befolyási övezetből lett „szocialista világrendszerrel” együtt saját, zárt világot, egyfajta alternatívát hozott létre a Nyugattal szemben. Az ideológiai szembenállás a fegyveres erők súlyával együtt kialakította a bipoláris világrendszert. A bipoláris rend „berendezkedésével”, létrejöttek azok a szerveződések, integrációk, amelyek a két fél támogatottságát voltak hivatottak elősegíteni. A világ folyamataiból, az együttmúködésekből történt kizárásnak fontos elemei lettek a gazdasági és humán jellegű szankciók, s főként a katonai szembenállás, a fegyverkezési verseny. Másrészt, propaganda jelleggel mindkét fél a 
másik ellehetetlenítését és saját ideológiajjának a terjesztését is célul tűzte ki.

A hidegháború - mint ez közismert globális geopolitikai, katonai, gazdasági és ideológiai szembenállás a Szovjetunió és szövetségesei; illetve az Egyesült Államok és szövetségesei között 1946-tól 1989-ig. Az ideológiák harcát - mint a társadalmi-gazdasági rendszerek kapitalista, illetve kommunista modellek szerinti múködése összeegyeztethetetlenségének következményét - tekinthetjük a konfrontáció lényegének.

A hideg-háború kettôs célt szolgált: a saját ideológia és az életmód propagandáját, egyedüliként elfogadtatását; valamint az „ellenséges” országok és a harmadik világ lakosságának tudatában a szembenálló blokk hivatalos ideológiájának és életmódjának a diszkreditálását.

Ez a harc számos síkon zajlott. Az egyik ilyen belső szembenállást is okozó terület a kultúra, főként az irodalom, a színház és a filmek világa. Az USA-nak és Nagy-Britanniának erre a feladatra létrehozott szervei különösen nagy aktivitással építették ki az „ellenzéki” szervezeteket a „szovjet blokk” országaiban.

Ma már dokumentálható, hogy szinte minden országban megjelentek az USA valamelyik „alapítványa” által létrehozott „szovjet-ellenes” szervezetek: például a Népimunka Szövetség (OUN), vagy a Wolność i Niezawisłość; a Solidarnost Lengyelországban; а Горянское Авижение Bulgáriában; de anyagilag támogatták az afgán modzsahedeket („Ciklon” operáció) is, és a nicaraguai „Contras”-t stb.
A másik oldalról, a Szovjetunió és szövetségesei pedig a nyugati blokk országaiban támogatták a kormányellenes erőket. Főként anyagilag segítették a kommunista pártokat, s néhány más baloldali- vagy békemozgalmat, és a nemzeti-felszabadító szervezeteket a harmadik világban.

Az ideológiai szembenállás talán leglátványosabb és sok ember számára közvetlenül is fájdalmas elemeként használták az ellentétes oldalon lévők kulturális sport- vagy humanitárius, segélyezési kezdeményezéseit és megnyilvánulásait. Ennek az ideológiai háborúnak esett áldozatául például a moszkvai olimpia 1980-ban, majd válaszul a Los Angeles-i olimpia 1984-ben. Az USA és szövetségesei közül sokan bojkottálták a moszkvai olimpiát 1980-ban, erre válaszul a Szovjetunió és szövetségesei bojkottálták a Los Angeles-i olimpiát 1984-ben.

Ez a „személyekre szabott” nyomás-gyakorlás különösen a szovjet emberek pszichikai „megdolgozását” tűzte ki célul. Főként pedig a Szovjetuniónak a világból történt kirekesztése és a saját bezárkózása teremtette meg a pszichológiai hidegháború múködőképességét. Ez eredményezte a szovjet emberek részéről a „vasfüggöny érzete” meghaladásának individuális kísérleteit, a „disszidálásokat”, vagyis az esetleges „külszolgálatról”, tanácskozásokról, „csoportosan engedélyezett turista utakról”, sportolók külföldi versenyzéséről, mûvészek sok pecsétes engedéllyel lehetôvé vált szerepléséről stb. a haza nem térést.

Ez a „gúzsba kötöttség” különösen frusztrálta - az egyébként is a sajnálatosan nem 
kizárható antiszemitizmustól rettegő - zsidó származású embereket, akik szerettek volna a közben - a szovjet segítséggel is - létrejött Izraelbe kivándorolni. A „kivándorlás akadályozása" miatt az USA által bevezetett szankciók pedig fokozták a Szovjetunió kirekesztésének nemzetközi elfogadottságát.

Ami a „kirekesztés/bezárkózás” dichotómiájának közvetlenül az emberekre gyakorolt hatását illeti, azt lehet megállapítani, hogy a szovjet hatalom egész történelme során csupán az áteresztő képessége, a „szivárgás” mértéke, aránya váltakozott, de a lényege nem. A polgárháború és a külföldi intervenció „hadi gazdaságát” követően, a konszolidáció, a NEP idôszakában valamelyest beindult a nemzetközi „mozgolódás”, de a 30-as évek belső „repressziós” folyamatai felerősítették a Szovjetunió „önelszigetelődését”. Már ekkortól beszélhetünk a köré alakuló „elválasztó függönyről”, illetve arról, hogy a határai szinte „frontvonallá” váltak.

\section{A hidegháború eszközei}

A hidegháború kezdeti időszakában a Szovjetunió ideológiai megnyilatkozásai ebben a kontextusban többek között az antikozmopolita kampány, a nagyorosz nacionalizmus és az antiszemitizmus voltak. A szovjetek oldaláról a „disszidens”-perek, a „szamizdat” ügyek stb. tartoztak még a hidegháború szellemiségének jellemzői közé.

Az ideológiai hidegháborúnak - főként amerikai részről - volt még egy „hatásos”, de nehezen beazonosítható eleme: a fegyverkezési versenyhez is kapcsolható közvetlen „pszichológiai hadviselés”. Az USA pszichológiai programja a Szovjetunió ellen, Reagan elnökségével kezdődött és 1981-83 között teljesedett ki. Ilyen volt például az „Able Archer 83" a NATO 10 napos vezetői gyakorlata egész Nyugat-Európára kiterjedően (lásd: Net1 - megj.: jelen értekezés igyekszik a nyílt, mindenki számára hozzáférhető események, történések feldolgozása alapján értékelni és következtetéseket levonni, ennek érdekében ahol lehet internetes forrásokra hivatkozik). Ebben az időszakban az eredetileg nem pszichológiai nyomásgyakorlásként induló esetek is könnyen válhattak a nemzetközi közvéleményt is befolásoló lélektani fegyverré. Jellemző példa erre a Korean Air Lines 007-es járatán repülő Boeing 747 lelövésének története, illetve a Vörös térre leszállt német egyszemélyes polgári repülő esete. A KAL 007 repülőgépet 1983. szeptember 1-jén hajnalban lőtte le a szovjet légvédelem egyik Szu-5TM típusú elfogóvadász repülőgépe. A repülőgép - fedélzetén 269 emberrel, közöttük egy amerikai kongresszusi képviselővel - New Yorkból tartott Szöulba, de a tervezett útvonaltól $300 \mathrm{~km}$-rel eltért nyugati irányban és átrepült a szigorúan titkosnak számító, katonai létesítményekkel teli Kamcsatka-félsziget felett. A hidegháborús pszichózis közepette a szovjetek a védelmi rendszerük szondázásának fogták fel a behatolást. Az incidens újabb hosszú időre a szovjet-amerikai kapcsolatok elhidegülését eredményezte.

Egy 19 éves német fiatalember vagány „kíváncsisága" még nagyobb ribilliót keltett Moszkvában. Mathias Rust, Sessna típusú 
gépével úgy repült át a szovjet határon, és tett meg ezernyi kilométert, majd ért földet 1987. május 28-án a szovjet fóvárosban, a Vörös téren, hogy a légelhárítás nem vette észre. A Szovjetunió biztonságáért felelős érintett szervezetek vezetőit azonnal eltávolították tisztségükből, s mindent átszerveztek, de ezt a pszichológiai vereséget már a hidegháború végéig nem tudták kiheverni.

Az ideológiai szembenállás mindkét oldalon összekapcsolódott a hírszerzői ütközésekkel. Ilyen volt a „Rosenberg-házaspár atomkémkedési pere", és az úgynevezett „mccarthyzmus”.

A mccarthyzmus Joseph McCarthy szenátor nevéhez füződik, aki az 1950-es évek elején az Amerikai Egyesült Államokban „boszorkányüldözést” indított a kommunista (gyanús) személyek ellen. Közalkalmazottakról, neves értelmiségiekről, művészekről állította, hogy kommunisták. Szinte minden esetben bizonyítékok nélkül idéztette az érintetteket az Amerika-ellenes Tevékenységet Vizsgáló Bizottság elé. Ha valaki alkotmányos jogaira hivatkozva nem volt hajlandó megjelenni és esküt tenni a bizottság előtt, hogy nem tagja a kommunista pártnak, rendszerint elvesztette állását, és állandó zaklatásnak volt kitéve, többnyire szovjet kémnek titulálták.

A KGB és a CIA szembenállására is számos példa adódik. Az egyik ilyen nagy port felvert eset az U-2 kémrepülő esete. Ugyancsak idesorolhatóak a lebukott kémek, politikai személyiségek cseréi is (például Luis Corvalan - Bukovszkij; Ábel ezredes Powers cseréje).
Az emberek ,agyáért” folytatott küzdelemben az ideológiai alapelvek is deformálódtak. Az „egyenlőség” eszményéből a szovjet gyakorlatban vulgáris értelmezésű egalitarizmus lett. De, a „nomenklatúra” kiváltságokat biztosított magának az ún. ,specboltokban”. A „hiánygazdaság” pedig ,horizontális újraelosztást”, vagyis pénznélküli kapcsolat alapú elosztást - „bartellt” eredményezett. Az egyre fokozódó gazdasági lemaradás nagymértékben vetette vissza a Szovjetunió és a szövetséges országokon belüli gazdasági-szociális viszonyokat. Ennek a pszichológiai hidegháborús nyomásnak az ellensúlyozása megjelent az SZKP, az „állampárt” belpolitikai döntéseiben. A Szovjetunió vezetése nem engedte gerjeszteni, kialakulni azokat a fogyasztási szükségleteket, amelyeket az ország saját erőforrásaiból, hosszútávon biztonságosan nem tudott kielégíteni. A Szovjetunió a teljes körű „önellátásra” rendezkedett be. A nehéz- és föként a hadiipari termelésbe fektetett óriási energia eredményeképpen kialakult „hiánygazdasággal” lehetett jellemezni ekkor a Szovjetuniót a kapitalista „többletgazdasággal” szemben.

Az erősen kiépült bürokratikus pártállam, az idős képviselők, vezetôk, nem tették lehetôvé a gazdasági, politikai megújulást. Bekövetkezett a „pangás” időszaka. A hidegháború még tartott, a fegyverkezés, a versengés pedig továbbra is oly mértékben nehezedett mind a nyugati, mind a szovjet társadalomra, hogy már nem csupán elszigetelten vetődött fel a kérdés: hová vezethet ez? Van-e tovább értelme az ideológiai harcnak? 


\section{Az „enyhülés” időszaka (1968-1975)}

Ennek a felismerésnek is köszönhetően az állandóan jelen lévő szembenállás, ellenségeskedés, a minden áron győzni akarás mellett - időnként megjelentek az enyhülés szándékai is. Először Sztálin halálát követően, a hruscsovi „desztalinizáció”, az „olvadás (оттепель)” - vö.: Чупринин (1990) eredményeként a Szovjetunión belüli ideológiai „eresztékek” lazulása keltett az 1960-as években reményt a nyugatiak körében az általuk hirdetett elvek szerinti együttmúködésre. Az érdemi enyhülés azonban akkor még nem következett be.

A hatvanas évek végére kialakult katonai egyensúly már lehetôvé tette a megegyezés szorgalmazását Az ezt követő időszakot nevezik a „détente”, vagyis az „enyhülés” időszakának: 1968 és 1975 között. A nagyobb szabású kiegyezés esélyét a Helsinki záróokmány megalkotása és aláírása 1975. augusztus 1-jén, hozta meg. Ez a dokumentum három fontos „kosarat” tartalmazott (Tarján, 1975):

1. Az európai biztonság kérdését.

2. A gazdaság, a tudomány, a technológia és a környezetvédelem területén az együttműködést.

3. A humanitárius és más területeken való együttmúködést (az áruk, emberek, eszmék szabad áramlása).

Az 1975-ben aláirt helsinki záróokmány az enyhülés csúcspontját jelentette, befejeződött az a folyamat, mely úgymond intézményesítette a hidegháború addig informális szabályait:

- befolyási övezetek elismerését,
- közvetlen konfrontáció kerülését,

- lemondást a nukleáris háború alkalmazásáról,

- kölcsönös fenyegetettség, a MAD (Mutural Assured Destruction, a kölcsönösen garantált megsemmisítés) egyensúlyhelyzetének elismerését,

- geopolitikai anomáliák (például Nyugat-Berlin) elviselését szemben azok konfliktussal fenyegető megszüntetésével.

A „helsinki folyamat” intézményrendszere új kooperációs távlatokat nyitott a gazdasági, környezeti, szociális kérdésekben. A záróokmányba „becsempészett” harmadik kosár fontos alapja lett a 80-as évek amerikai pszichológiai akcióinak a szovjetek ellen. Ha úgy tetszik ez volt az ideológiai szembenállás trójai falova - hiszen aláírták a szovjetek. Az ütközőzónák megmaradása szintén kódolta a viszonyrendszerbe az egyik fél lehetséges vereségét. A záróokmány aláírását követő 10 évben ismét felerősödő regionális konfliktusok (a két hegemón támogatása mellett), az afganisztáni bevonulás, az olajárrobbanások kiváltotta gazdasági válság és az elhidegülő nagyhatalmi kapcsolatok rávilágítottak a nemzetközi rendszer gyengeségeire, a megoldás egy új formáját igényelve.

Az enyhülés időszakában mindkét oldalról megtett lépéseknek is köszönhetően a világ olyan állapotba került, hogy szinte láthatóvá vált a hidegháború végének „célszalagja”. A „kézenfogva-befutó” helyett azonban elkeseredett küzdelmű végjáték kezdődött a győzelemért. Mind az USA, mind a Szovjetunió győztesként akarta lezárni a hidegháborút. A 
felek újra rendezték soraikat és mozgósítva minden erőforrásukat, ismét egymásnak feszültek.

\section{A „kis hidegháború” időszaka (1979-1985)}

Az USA-ban, a 70-es évek végének kompromisszumok által megegyezésekre törekvő, demokrata párti Jimmy Carter elnökségét gyengeségnek titulálva, az 1980-as választáson visszatértek a konfrontatívabb republikánusokhoz. A Ford- és Carter-kormányok a harmadik világbeli szerepvállalással szemben az izolációs politikát részesítették előnyben. Az amerikai választókat a demokraták külpolitikai kudarcai (iráni túszdráma) és a nemzetgazdaság állapota az 1980. évi elnökválasztáson a republikánus Ronald Reagan mellé állították. Amerikának olyan vezetőre volt ismét szüksége, aki megerôsíti az amerikai kivételesség hagyományos elveit. Ami Reagant kiemelte a sorból, az ennek az eszmének a szó szerinti alkalmazása volt a külpolitikában. A szovjet expanzióra eltökélt konfrontatív stílusban adott választ, az USA-t „a mai világ legnagyobb békeerejének” titulálta, és kimondott célja volt a „demokráciák” feltétlen támogatása, a demokrácia eszméjének aktív terjesztése - azaz logikusan végigvitte a wilsonizmust. Programjának alapja a tartós növekedést felmutató gazdasági alapok megteremtése és az USA biztonságát garantáló katonai képességek kialakítása volt. Az amerikai-szovjet csúcstalálkozók 1979 és 1985 között szüneteltek, a csúcsdiplomácia helyett az ideológiai és propagandaháború kapott szerepet a „kis hidegháború” időszakában. Ronald Reagan elnöksége megfelelt a várakozásoknak a „kommunizmus legyőzésére”. 1983-ban tanácsadói (többek között Teller Ede) javaslatára meghirdette az SDI-t (Strategic Defence Initiative, Stratégiai Védelmi Kezdeményezés), vagy, közismertebb nevén, a csillagháborús programot, amelynek kulcsszerepe volt a Szovjetunió végleges megroppantásában. A fegyverkezési verseny újraindítása jegyében közép-amerikai államok-ban tervezett intervenciót, az ottani USA-val ellenséges rezsimek megdöntése céljából. Az ellenzékiek felfegyverzésén és támogatásán kívül Nicaragua esetében a légierő bevetésére is sor került. 1983-ban a szovjetveszélyre hivatkozva, amerikai csapatok megszállták Grenadát és megdöntötték Maurice Bishop kubai típusú rezsimét. A Szovjetunió és Afganisztán között kirobbant konfliktusba direkt módon nem avatkozott be, de támogatta a szovjetellenes terrorista akciókat elkövető mudzsaheddineket.

Nagy nemzetközi sajtóvisszhangot váltott ki a második elnöki ciklusában kirobbant Irán-Kontra botrány, melyben kiderült, hogy az USA fegyvereket adott el - az akkoriban Irakkal háborúskodó - Iránnak, és a befolyt pénzekből a nicaraguai ellenzéket (kontrák) támogatta gerillaakcióikban. Reagan elnök a National Medal of Science kitüntetést adta Teller Ede professzornak (1983). A kortársai által csak „Nagy Kommunikátornak” nevezett Reagan - retorikai képességeinek köszönhetően - bármilyen szituációból képes volt politikai tőkét kovácsolni magának. Mind a Challenger-katasztrófáról szóló beszéde, 
mind Nyugat-Berlinben a fal lebontásának szükségességéről elmondott beszéde („Gorbacsov úr, bontsa le ezt a falat!') nagy hatással volt hallgatóságára. Az Amerikai Egyesült Államokban úgy tartják, hogy kulcsszerepe volt a Szovjetunió megdöntésében (Andor, 1999).

Állíthatjuk, hogy ha a hidegháború meghirdetésének Winston Churchill 1946. március 5-én elhangzott híres „fultoni beszédét” tekintjük, akkor a Nyugat által elképzelt végét Reagan „harangozta be” 1982. június 8-án Londonban, a brit parlamentben elmondott „antikommunista kiáltványában” (Reagan, 1982). Ebben a szovjet rendszer bukását jósolta meg. Itt lényegi momentum, hogy a beszéd középpontjába a szovjet-amerikai viszony elhidegültsége került, amely a Szovjetunió legyőzésének eszméjében teljesedett ki, örökidőre „ráragasztva” a „Gonosz Birodalma” jelzőt, ezzel is elutasítva az együttműködés bármilyen formáját.

Reagan (1982) erősen ellenezte a kommunizmust, a brit népet pedig beszédében arra bíztatta, harcoljon a szabadságért, ahogyan Winston Churchill tette a náci uralommal szemben. Említést tett a START programról is.

A szovjet vezetôk nem jól mérték fel, hogy az Egyesült Államok kormánya ekkor már titokban, a hidegháborús stratégiának megfelelően kezdte meg az ellentétes oldalon harcoló kormányellenes mudzsahedek felszerelését és kiképzését (Net3).
Eközben az USA-ban megkezdődött a „végső harcot” megalapozó hazai rendteremtés (ezt a koncepciót azóta a „reaganomics" fogalommal illetik, amely a kilábolást tette lehetővé az elhúzódott gazdasági válságból - lásd: Net4), amely egyfajta pszichológiai nyomásgyakorlást is jelentett a szovjet emberekre, katonai vezetőkre. Továbbá felkészítették a Szovjetunió összeomlását követő ideológiai, politikai, gazdasági vákuum „,kitöltésére” képes „Amerika-barát” vezetőket a „szocialista országokban”. Reagan 1982. júniusi beszédében megfogalmazott stratégiához tartozott azon projektek létrehozása, amelyek felkészítik a SZU és a szocialista országok aktivistáit a nyugat győzelmének elősegítésére, az ezekben az országokban várhatóan kialakuló ideológiai-politikai vákuum kitöltésére, illetve a majdani új rendszert vezető politikai elitjének a szerepére. Ezeknek a projekteknek a vezénylésére hozták létre az USAID és NDI szervezeteket Madeleine Albright égisze alatt, az Einstein Alapítványt és Intézetet Gene Sharp irányításával. Mindezek működését, finanszírozását, hatékonyságát a Republikánus Párt szenátora, McCain koordinációja biztosította.

Erről sok közvetlen információ nem áll rendelkezésre. Néhány olyan személlyel folytatott beszélgetés alapján, aki részese volt a „kiképzésnek”, illetve a Marc Berdugo francia rendező 2005-ben készített dokumentum filmje segítségével lehet rekonstruálni, aminek címe: Les États-Unis à la conquête de l'est (lásd: https:/ / www. youtube.com $/$ watch? $\mathrm{v}=5 \mathrm{n} 6 \mathrm{qO}$ OhIuzrk). 
A felkészitések tartalmáról részletesebben Gene Sharp filmje nyújt tájékoztatást: De la Dictatura a la Democracia (The Albert Einstein Institution, Boston, 2003), ami magyarul „Hogyan csináljunk forradalmat?" címmel feliratozott filmként jelent meg (lásd: https://www. youtube.com/watch? $\mathrm{t}=14 \& \mathrm{v}=\mathrm{HrRYw} 8 \mathrm{je}$ Rl0. Lásd még: Az erőszakmentes beavatkozás 198 módja. http://www. slideshare.net/exopolitika/gene-sharp-azerszakmentes-beavatkozs-198-mdja

Reagan nem válogatott az eszközökben, céljait konfrontáció útján igyekezett elérni. Közbülső megoldást nem látott az állandó konfliktus és a végleges kibékülés között. Ebből adódóan az amerikai propaganda igyekezett a hidegháború fontosságát visszavezetni a köztudatba. Ebben a korszakban készültek például olyan filmek, melyek egy lehetséges nukleáris összecsapás problémáját vetették fel az amerikaiak és a szovjetek között (lásd: Másnap, Fonalak stb. címú filmek). Az armageddon elkerülése érdekében akár a Brzezinski-féle teljes megsemmisítés (Brzezinski, 1965), akár a Kissingerféle tárgyalásos térdre kényszerítés taktikáját alkalmazva (Kissinger, 2008), de a hidegháborút győztesen kellett befejezni.

Az akkoriban éppen - a már említett „pangás” állapotában lévő Szovjetunió vezetése sem tétlenkedett. A döntéshozói szinten ugyan „megállt az idő”, s a gerontokrácia érvényesült, mégis erőt mutattak fel. A Szov- jetunió 1979-ben, a „világforradalmi folyamat” ideológiai elvéből kiindulva, „korlátozott kontingenssel" fegyveresen avatkozott be a kialakult belháborúba, az egyik afganisztáni politikai szervezetet, az akkor kormányon lévőket támogatva (v.ö.: Net5, Net6, Net7). Fel sem tételezték, hogy ezzel a döntéssel végleg elvágták a hidegháború győztes befejezésének lehetőségét. A Szovjetunió beleragadt az afgán törzsek közötti kibékíthetetlenség évszázados „mocsarába”.

Ugyanakkor a Szovjetunió „,belviszonyaiban" felerősödtek olyan jelenségek, amelyeket egyes mai elemzők ,árnyék gazdaságnak” (теневая экономия) vagy „második gazdaságnak" neveznek (lásd: Net8). A Szovjetunió szociális-gazdasági modelljét a „pangás” időszakára vonatkozóan sokan ,állam-kapitalizmusnak" tekintik, bár formálisan az állami vállalatok „privatizációjára” nem került sor, de azok a „pártállami” bürokrácia, a „nomenklatúra" osztatlan fennhatósága alá tartoztak. Ez az árnyék-gazdaság, lényegét tekintve, a „szocialista elveket” elvetve múködött, különbözőképpen, de átjárta a korrupció, az állami vagyon eltulajdonítása, és a törvények megszegésével vagy a ,joghézagok" kihasználásával járó ellenőrizetlen jövedelemszerzés.

Mindez összefonódott a szervezett bűnözéssel, a „törvény szerint tolvajokkal” (воры в законе)", az állampárti nomenklatúra vezetőivel. Időnként felvették a harcot ezekkel a „népellenes” jelenségekkel. Számos hangzatos perre, sőt halálos ítéletre is sor került. Andropov hatalomra jutásával ez felerősödött, mégis az árnyék gazdaság kiépülése lett 
az egyik fontos eleme a szocializ-mus szovjet modell szerinti eróziójának (Net9, Net10).

Az 1980-as évekre a rendszer egészét befolyásolni képes néhány negatív tendencia vált meghatározóvá a Szovjetunióban. A már említettek:

- a hidegháború győzelemre vitelének új szemléletű törekvései az USA részéről; a gazdaság „lefullasztása” a még fokozottabb és ürtechnikára alapozott minőségű fegyverkezési versennyel, valamint a nyersanyag, s különösen az olaj, gáz árak minimalizálásával;

- az ideológiai szembenállás szélsôséges kiéleződése a szovjet emberek pszichológiai célbavételével;

- a hazai feszültségek (a vezetés ,gerontokráciája”, az árnyékgazdaság kezelhetetlensége, az afganisztáni intervenció stb.) bizalmatlanságot növelő hatása mellett még mélyebb, hosszútávon érvényesülő erodálódást okozó tendenciák is jelentkeztek.

\section{A hidegháború végjátéka (1985-1989)}

1985. március 11-én Mihail Gorbacsov lett a Szovjetunió Kommunista Pártjának főtitkára. Gorbacsovékat az országban kialakult szociális feszültségek, az üres polcok, a felerôsödött infláció, az „árnyék gazdaság” tobzódása, a nemzetközi szintéren az ország „zárványosodása” rádöbbentette, hogy más irányban és más módon kell a Szovjetuniót új pályára állítani. Gyökeres változtatások váltak szükségessé, amelyek következtében az ország rákapcsolódhat a világban kialakulóban lévő új globalizációs folyamatokra, s részese, alakítója is lehet az interdependenciának, az egységesülő munkamegosztásnak. Az informatikai forradalom korában tovább nem lehet elzárva tartani a világ többi részétől egy ilyen kiterjedt birodalmat. Ha mégis a korábbi gyakorlatot követték volna, akkor ismerve a Szovjetunió belső viszonyait, az elzárkózásból is fakadó elmaradottságot bizonyára rövid időn belül olyan társadalmi robbanás rázkódtatja meg az országot, hogy az egész emberiség látja a kárát. Ezt csak egyféleképpen lehetett megakadályozni, mégpedig úgy, hogy megkísérlik integrálni a világ egészébe, megkísérlik átállítani a civilizációs fejlődés fö útvonalára. A Szovjetunió azonban ebben az időben semmilyen tekintetben nem volt integrációképes.

Gorbacsov felismerte, hogy a Szovjetuniót - gazdasági, politikai és szövetségi rendszerét - teljes egészében meg kell változtatni ahhoz, hogy be tudjon kapcsolódni a világfejlődésbe. Kérdés volt ugyanakkor az is, hogy a fejlett világ képes-e, s ha igen, milyen formában hajlandó befogadni a Szovjetuniót. Gondoljuk csak végig, hogy a nyugati politikusok milyen változatokat kínáltak. Egyesek azt tanácsolták, hogy a Szovjetunió ismerje be vereségét, a társadalom-átalakítási kísérlete sikertelenségét, s a fejlett tőkés világ értékeit feltétel nélkül elfogadva készüljön fel az integrációra. Mások úgy gondolták, hogy miután úgysem lesz képes és készséges a polgári társadalom elfogadására, nem marad más hátra, mint a határainál lehúzni az újabb vasfüggönyt, miután megszabadították a befolyási övezeteitől. S csak kevesen gondoltak 
arra, hogy valóságos kompromisszumokra vagyis a Szovjetunió átalakulása mellett a nyugat bizonyos változásaira - is szükség van. Holott, ha a történelmet és a tényleges erôviszonyokat jól átgondolják, kikövetkeztethetik, hogy ez az egyedüli és a Szovjetunió számára is elfogadható változat. A gorbacsovi peresztrojka lényegét talán úgy lehetne egyetlen mondatban megfogalmazni, hogy szükség van a Szovjetunió átalakítására ahhoz, hogy a világ fejlődésébe integrálódni tudjon, de arra is szükség van, hogy a világ átalakuljon, mert csak így képes befogadni egy új Szovjetuniót, csak így lehetséges az átalakított világba szervesen bekapcsolni az átalakított Szovjetuniót. Az országon belüli fejlődést eredményező átalakulásokhoz, szükségessé vált az integrálódás a világgazdaságba. Ennek pedig a kiindulópontja az új politikai gondolkodás a külpolitikáról, a nemzetközi rendszerről és a kapcsolatokról. A tétje pedig: a túllépés a hidegháborún.

Levonható a következtetés mindebből. Bár a két globális hatalom 1975 óta, a helsinki folyamat kibontakoztatása során a békés egymás mellett élés intézményesítésére törekedett (például 1989. január 19-én Bécsben befejeződik az Európai Biztonsági és Együttmûködési Értekezlet, melyen a részt vevô 35 ország egyezményt írt alá az emberi jogokról és Románia kivételével az aláírók kötelezték magukat annak betartására), a valóságban a hidegháború megnyerése volt továbbra is mindkét fél célja.

A szovjetek mindeddig fenntartották a „világforradalmi folyamat” ideológiájából adódó stratégiai terjeszkedésüket. Elég volt bárhol - Szomáliában vagy Kambodzsában, Nicaraguában vagy Afganisztánban - kijelenteni, hogy győzött a „szocialista-forradalom”, és a Szovjetunió máris politikai, gazdasági és nem utolsósorban fegyveres segítséget nyújtott. A katonai jelenlét széleskörű biztosítása azonban meghaladta a szovjetek gazdasági erejét.

Ennek felismerése a szovjet politikai osztályban vezetett ahhoz, hogy egyre többen tették magukévá - a nyugati polgárság köreiben már az ötvenes években kialakult koncepciót, amely szerint a két ideológiai tábornak - a kapitalizmusnak és a szocializmusnak - meg kell tenni a szükséges lépéseket afelé, hogy egymást nem fenyegetve, hanem elfogadva alakítsák a világ folyamatait. Ugyan egyik fél sem tette magáévá a konvergencia gondolatát (sőt, mint láttuk, a kezdeményezések mögött is jelen volt a győzni akarás a hidegháborúban), mégis a világ „megnyugtatására” szükségesnek látták egyfajta „mosoly-diplomácia” kialakítását.

A hidegháború befejeződéséhez az utolsó lépést Gorbacsov mellett már az új amerikai elnök, George Bush tette meg. A máltai találkozón 1989. december 2-3-án deklarálták a hidegháború befejezését (Net11). Az ott született megállapodások tartalmát illetően csak következtethetünk a nyilatkozatok és kommentárok nyomán, hiszen mind a mai napig nem hoztak nyilvánosságra hivatalos, a két fél által aláirt dokumentumot. A megegyezés létezését azonban maga Gorbacsov erősítette meg, majd ezen „papírok” hiányára utalt V. Putyin a Valdaj Club 2015. októberi találkozóján, megjegyezve, hogy eljött az ideje 
közzé tenni például a német-újraegyesítéssel kapcsolatos dokumentumokat (v.ö.: Net12).

Máltán szóbeli megállapodás született arról, hogy „abbahagyják” a hidegháborút. A „Gorbacsov Alapítvány” kiadványában - amelyben részletesen tették közzé a gorbacsovi időszak valamennyi nemzetközi politikai tárgyalásának belső dokumentumait és a tárgyalásokról készített feljegyzéseket - a máltai megállapodás összegzéseként mindössze a következő szerepel (Gorbacsov, 2010):

„Elismerték, hogy a Szovjetunió és az Egyesült Államok többé nem »ellenségek«, kinyilatkoztatták, hogy befejeződött a »hidegháború« és a konfrontáció. Az USA új adminisztrációja nyilvánosan támogatásáról biztosította a peresztrojka politikáját."

A máltai tárgyalások második napján elhangzott a kulcsmondat Gorbacsov szájából: „A Szovjetunió kész nem ellenségként tekinteni az Amerikai Egyesült Államokra.” Gorbacsov kijelentésének úttörő szerepét mutatja, hogy Bush elnök „csak” 4 hónappal később, 1990 áprilisában, Sevarnadze külügyminiszterrel folyatott tárgyalása során jelentette ki, hogy „az ellenség nem a másik oldalon van, hanem a kiszámíthatatlanságban és az ingatagságban".

A diplomácia nyelvéről lefordítva Gorbacsov kijelentése azt jelentette, hogy a szembenállást megszüntetve lebontják a Szovjetuniót a világból kirekesztő vasfüggönyt, s ezzel együtt támogatják a bezárkózást felszámoló peresztrojka megvalósulását.

\section{A hideghárború végének narratívái - avagy: variációk egy témára}

A hidegháború végének eredményeképpen elvileg megszűnt a kétpólusú világrend. Itt két alapvető megállapítást kell tenni: egyrészt a Szovjetunió „visszavonulásra” kényszerült az ideológiai harcból, de a hadászati egyensúly fennmaradásából következően, a helyzetet a hidegháború ,abbahagyásaként” fogta fel.

M. Gorbacsov használta az „abbahagytuk (прекратили)" kifejezést a Szerzővel folytatot beszélgetésben.

Másrészt, az USA ,vesztes félként” tekintett a Szovjetunióra, és saját magát pedig a hidegháború győztesének kiáltotta ki. Ez azért fontos megállapítás, mert a két hatalom közötti viszonyt a mai napig ez a két ellentétes feltevés határozza meg. A kilencvenes években az Egyesült Államok ideológiája arra épült, hogy ezzel a győzelemmel, egyrészt, ki lehet terjesztenie saját társadalmi-politikai rendszerét a világ egészére; másrészt, a Szovjetuniót, mint legyőzöttet, az USA alávetettjeként kezelheti, s ekként meg kell akadályoznia abban, hogy újra képes legyen a győztesek hatalmát megrendítő potenciállá válni. A 90-es évek - főként a Szovjetunió megszüntetése, a föderációt addig alkotó orszá- 
gokra szétszedése során - valóban az USA győzelmét látszottak igazolni. Arról nem is beszélve, hogy Z. Brzezinsky Budapesten hivatkozott arra, hogy a Szovjetunió megszűnt, ezért az egyedüli győztes az Egyesült Államok, egy nem létező állammal kötött megállapodás pedig miért lenne a továbbiakban érvényes bárkire?

További értelmezésre váró kérdés az országok, rendszerek, népek és az egyes emberek közötti szükségszerű és elkerülhetetlen kapcsolatok, együttmúködés minőségének a megítélése a Szovjetunióban lezajlott események tanulságaként. A kérdéshez alapot ad az a retorika, amellyel az USA elnöke, George Bush a világnak drámai hangsúllyal jelentette be (idézi Valerij Szudorov, lásd: Net13): „Hatalmas a győzelmünk a Szovjetunió felett, méghozzá a belső ellenzékük által.”

Mielőtt azonban a külső „összeesküvés” elméletét és gyakorlatát tennénk „felelőssé” a világ legnagyobb „birodalma” széteséséért, illetve hozzákapcsolnánk a „belső ellenség” árulását, győződjünk meg arról, hogy helytálló-e a tézis. Ahogyan egyre-másra megnyílnak a titkosszolgálati archívumok is, fokozatosan megjelennek elemzések, amelyek más összefüggésekben mutatják be a történteket. Ilyen például az az összeállítás, amely a Reagan felügyeletével létrehozott „NSDD terv" végrehajtásában fedezi fel a Szovjetunió megszűnésének lényegét. A terv arról szól, hogy a 70-es évek „egymás mellett élés” programjai helyett elkövetkezett az idő a SZU legyőzésére, s kijelöli a terv realizálásának útjait, módjait (Net14). Természetes, hogy ilyen történelmi horderejű esemény szereplői a „saját lovukat” dicsérik. A Szovjetunió megszűnésének bejelentését az USA-ban „győzelmi mámorral” ünnepelték. Az USA valóban csupán az ellenségét vesztette el a Szovjetunió megszűnésével, a hidegháború befejezésének más negatív következményei nem érintették. Az elnök - aki végig tevékeny részese volt mind a hidegháború lezárása, mind azután a Szovjetunió „felszámolása” folyamatának - méltán lehetett büszke a teljesítményére. A Szovjetunió nincs többé az utódokról pedig még nem kell számot adni. Bár azzal, hogy a „belső ellenzéket” magához kapcsolta, közvetve utalt a jövő lehetőségeire is. Olyanok igazgathatják az utódállamok sorsát, akikkel korábban „összehangolódtak". Olyan rejtvény bontható ki mindebből, amelyből számos következtetés vonható le a jövőbeni együttélés minőségét illetően. A hidegháborúban talán még fontosabb szerepet játszott a "bumán tényezo" mint a ,forró" háborúkban. Kicsit egyszerűsítve: a „forró” háborúban az embereket megsemmisítik, miközben a hidegháborúban az ,átalakításukra”, az ellenség törekvéseinek az elfogadására és annak szolgálatában a saját pozíciók feladására vonultatnak fel - kölcsönösen erőket. Tény, hogy az „információs” és „pszichológiai” hadviselés az USA részéről sikeresebb volt. Bizonyításként értékes lehet a „végjátékban” tapasztaltakat hasznosítani.

Az USA vezetôi - és nyomukban az egész nyugati szövetségbe tartozók - elsődlegesen a saját győzelmüknek igyekeztek beállítani a történteket. Érdemes kibogozni a máltai megegyezés utáni tárgyalásokból, egyéb jellegű kapcsolatokból a Nyugat törekvéseit a 
„döntetlen” elfogadásának győzelemre transzformálására. Megérezték Gorbacsov gyenge pontjait, bizonytalanságait, és közben erősítették a „trónkövetelőket”. Szinte lehetetlen pontosan bemérni, hogy mikortól datálható az „oszd meg és uralkodj” metodika intenzívebbé tétele.

Azt is meg kell jegyezni, hogy az amerikaiakat Málta után főként az foglalkoztatta, hogy a szovjet nukleáris arzenál felett ki rendelkezik és hol találhatók majd ezek a stratégiai erôk. A Szovjetunió politikai-ideológiai rendszerétől akartak mindenáron megszabadulni, és részükről a befolyásolás erre összpontosított, s nem a tagköztársaságok leválasztására. A fordulat a GKCSP leverése során következett be, amikor kiderült, hogy Jelcin vezetésével az Oroszországi Föderáció képes lesz önálló országként megmaradni és az amerikai érdekeknek megfelelően működni. A Legfelsőbb Tanács zárt ülésén Krjucskov KGB elnök ismertette azt a jelentést, amelyet még Andropov tett az SZKP KB asztalára 1977-ben „A CIA terveiről befolyást gyakorló személyek beszervezéséről a szovjet emberek közül" címmel - lásd: Судоплатов (1996, 76. о.).

\section{A hidehárborúnak mégsem lett vége 1989-ben}

Az USA stratégiájának és taktikájának a fejlődésérôl az elemzett folyamatokban kiderül, hogy a kezdetektől a szovjet rendszer ideológiáját akarták mindenáron kiiktatni a „történelemből” - emlékezzünk Reagan híres mondatára: „a történelem hamudombján hagyni a marxizmust-leninizmust" -, s akkor segítették elő a Szovjetunió (a volt Orosz birodalom!) szétesését, amikor elsősorban azt már a belső erők ambicionálták. Ebből adódik, hogy a hidegháború lezárásának az USA nem a máltai kiegyezést tekinti, hanem 1991. december 26-át, a Szovjetunió megszünése bejelentésének dátumát. $\mathrm{Ez}$ a körülmény indokolja azt a ,hideglelős” reakciót, amelyet bármilyen kísérlet kivált a Szovjetunió visszaállítására.

Az Oroszországi Állami Duma 1996. március 15-i döntése határozatban fogalmazta meg a Szovjetunió megszüntetésének alkotmányellenességét. „A Szovjetunióban egységesült népek integrációjának elmélyítéséről, és az Orosz SZFSZK Legfelsőbb Tanácsának 1991. december 12-i, a Szovjet Szocialista Szövetségi Köztársaság megőrzésének tárgyában a Szovjetunió 1991. március 17-i népszavazásának a kérdésrôl hozott határozatának a hatályon kívül helyezéséről" címú határozatban a képviselók az eltelt öt év tapasztalatai alapján megállapították a népakarat semmibevevését.

Az amerikai reakció még inkább vonatkozik az „Eurázsiai Unió” létrehozásának bejelentésére, amelyet az USA egyértelműen a Szovjetunió visszaállítására tett kísérletnek fog fel.

Az USA Kongresszusa 2007. április 12-én törvényt fogadott el új hadi emlékérem bevezetéséről: „részvételért a hidegháborúban (Cold War Service Medal)" elnevezéssel. Mindazok kapják, akik 1945. szeptember 2. és 1991. december 26. közötti időben katonaként, állami intézményekben szolgálták az Egyesült Államokat. A törvénytervezet vi- 
tájában az is elhangzott, hogy az USA hadserege a hidegháború idején összesen 407316 fôt veszített el (Net15). Hillary Clinton a demokraták előterjesztését azzal indokolta, hogy a „győzelmünkkel a hidegháborúban hatalmas eredményt értünk el ... sok millió amerikai részvételi készségének köszönhetően”. Robert Andrews képviselő pedig még egyértelmúbbé tette az amerikai felfogást a történtekről (Net16, részletek: Мединский, 2011):

„A hidegháború globális hadmúvelet volt, méghozzá nagyon veszélyes és olykor halálos kimenetelú a bátor katonáink, tengerészeink, pilótáink és deszantosaink számára, akik részesei voltak ennek a háborúnak. A több millió amerikai veterán, aki szerte a világban szolgált azért, hogy megnyerjük ezt a konfliktust, megérdemli az elismerés érmét."

\section{Irodalom}

A helsinki záróokmány. Letöltés: 2019.05.03. Web: https://www.osce.org/helsinkifinal-act

Andor László (1999): Amerikai politika a 20. sqázadban. Útmutató Kiadó, Budapest

Bræzezinski, Z. (1965): A megosztottság alternativája. MSZMP zárt, számozott kiadványa, Budapest

Судоплатов, П. А. (1996): Разведка и Кремль. Москва: Гея
Gorbacsov, M. (2010): Отвечал на въъзов времени. Москва: Издательство «Весь Мир».

Чупринин, С. (1990): Ommenель: 1960-1962. Москва: Московский рабочий

Kissinger, H. (2008): Diplomácia. Panem Kft., Budapest.

Мединский, В. Р. (2011): Война. Мифъ СССР. 1939-1945. Москва: ЗАО «ОАМА МеАиа Групп»

Net1: Letöltés: 2019.05.02. Web: http:// unienc.ru/274/931417-psihologicheskieoperacii-ssha-protiv-sssr.html.

Net2: Az EBESZ Története. Letöltés: 2019. 05.02. Web: http://www.mfa.gov.hu/ kulkepviselet/AT_EBESZ/hu/az+EBES $\mathrm{Z}+$ tortenete/EBESZ+tortenete.ht

Net3: Партизанская война в Афганистане (1979-1989). Letöltés: 2019.05.02. Web: http://www. modernarmy.ru/article/42.

Net4: Laffer, A. (s.a.): The Four Pillars of Reaganomics. Letöltés: 2019.05.02. Web: http://www.heritage.org/research/repor ts/2007/01/the-four-pillars-of-reaganom ic

Net5: Сергей Аружиловский: K 30-летито ввода советских войск в Афганистан. Letöltés: 2019.05.03. Web: http://www.mgimo.ru/ afghan/134482.phtml

Net6: Гоков, О. А. (2009): Причины ввода советских войск в Афганистан в 1979 году. Военно-исторический журнал, 2009., № 12., 43-44. Letöltés: 2019.05.03. Web: http://ricolor.org/history/rsv/aft/22_01_201 $1 /$

Net7: Клинчевич: СССР бъгл прав, введл войска в Афганистан. Letöltés: 2019.05.03. Web: 
http://www.bbc.com/russian/russia/201

4/12/141224_afghanistan_klintsevich_int erview

Net8: Катасонов, В. (2014): «Теневики». Капитализм в недрах СССР подспудно вызревал на протянении трех десятилетий. Letöltés: 2019.05.03. Web: http://www. stoletie.ru/territoriya_istorii/teneviki_ 230.htm

Net9: Simis, K. (1982): The Corrupt Society. The Secret Word of Soviet Capitalism. New York: Simon and Schuster. Letöltés: 2019.05.03. Web: https://archive.org/details/ussrthe corruptso00simi

Net10: Козырев, М. (2012): Подпольныле миллионерь: вся правда о частном бизнесе в CCCP. Letöltés: 2019.05.03. Web: http:/ /iknigi.net/avtor-mihail-kozyrev/ 50318-podpolnye-millionery-vsya-pravdao-chastnom-biznese-v-sssr-mihail-kozyrev $/ \mathrm{read} /$ page-1.html

Net11: Горбачев, $M$ (s.а.): Мальта. Hачало конща «холодной войньъ» Евгений Черньхх, Андрей Баранов: На Мальте Горбачев сдал CССР со всеми потрохами. Letöltés: 2019.05.03. Web: http://www.kp.ru/ daily/26313.3/ 3190444/

Net12: Заседание Международного дискуссионного клуба «Валдай» Letöltés: 2019. 05.03. Web: http://kremlin.ru/ events/ president/news/ 50548
Net13: Валерий Сидоров: Как зарождался ельЦинизм, или «Штау» натворили «зубрыъ»в Беловенской Пуше 8 декабря 1991 г.? Часть 2. Letöltés: 2019.05.03. Web: http:// netler.ru/articles/belavezha-signing-2.htm Net14: Letöltés: 2019.05.03. Web: http:// www.russlav.ru/aktualno/raspadsssr.html

Net15. Letöltés: 2019.05.03. Web: http:// web.stanford.edu/ jgrimmer/Website/Jo int/File226.txt. és http://www. american coldwarvets.org/cold-war-casualties

Net16: «3а победу над русскими. Америка представила себя $\kappa$ награде». Letöltés: 2019.05.03. Web: http://www.kommer sant.ru/doc/758952

Reagan, R. (1982): Address to British Parliament. The History Place Great Speech Collection. Letöltés: 2019.05.02. Web: http://www. historyplace.com/speeches/reagan-parlia ment. htm

Tarján M. T. (1975): Az Európai Biztonsági és Együttmüködési Értekęlet megnyitása, 1975. július 30. Letöltés: 2019.05.02. Web: http://www.rubicon.hu/magyar/oldalak/ 1975_julius_30_az_europai_biztonsagi_es _egyuttmukodesi_ertekezlet_megnyitasa/ 